in its relations to other sciences. The first full constitutive general assembly may be delayed for a year or two, until a full-scale international gathering becomes desirable after the meeting in 1946; but the committee charged with preparing the formation of the Union has been authorized to carry on meanwhile as the executive committee. The acting general secretary is Dr. R. C. Evans, Crystallographic Laboratory, Cavendish Laboratory, Cambridge, England, to whom all correspondence should be directed.

\section{Acta Crystallographica}

THE most urgent task confronting the new Union of Crystallography is the re-establishment of an international journal for publishing crystallographic research. Thanks to generous financial support from the United Nations Educational, Cultural and Scientific Organisation and from many research associations and industrial organisations in Britain, preparations are now well advanced for the launching in January 1948 of Acta Crystallographica, a journal to appear in six issues a year under the editorship of Prof. P. P. Ewald (Queen's University, Belfast, Northern Ireland), with Dr. R. C. Evans (Crystallographic Laboratory, Cavendish Laboratory, Cambridge, England), Prof. I. Fankuchen (Brooklyn Polytechnic Institute, 99 Livingston Street, Brooklyn 2, N.Y., U.S.A.), Prof. A. V. Shubnikov (c/o Academy of Sciences, Moscow, U.S.S.R.) and Prof. J. Wyart (Laboratoire de Minéralogie, La Sorbonne, 1 rue Victor-Cousin, Paris V, France) as regional co-editors. The Cambridge University Press will be the publishers and general distributors; but by arrangement of the American Institute of Physies it will be possible for subscribers in North America to pay their subscription through that Institute. Authors wishing to submit papers in English, French, German or Russian are asked to send them to Dr. Evans or Prof. Fankuchen, Prof. Wyart, Prof. Ewald, and Prof. Shubnikov, respectively, according to the language used.

\section{Council for the Promotion of Field Studies}

THE Council for the Promotion of Field Studies announces that it has gratefully accepted the generous offer of the Court of the Worshipful Company of Goldsmiths to provide the sum of $£ 6,000$ for the establishment of a residential field study and research centre at Malham Tarn House, near Settle, Yorkshire. It is desired that the gift should be associated in name with the Goldsmiths' Company, and that a portion of it should be used to set up a rock and water garden for plants in their natural setting. Last year this property of 457 acres, including the tarn and tarn moss, came into possession of the National Trust, which offered to lease it to the Council. Malham Tarn House is situated in a district of great geological, ecological and archæological interest, and for certain branches of study the position of this field centre will be unique in the British Isles.

The Carnegie United Kingdom Trust, through the generosity of which the Council was enabled to open its pioneer field centre at Flatford Mill in 1946, has recently made a further grant of $£ 5,000$ to complete the establishment of that centre. Further centres are being established at Juniper Hall, near Box Hill, Surrey, and at Dale Fort, on the Pembrokeshire coast.

Prof. A. G. Tansley has accepted the office of president of the Council, and the executive committee has made the following appointments : Director and
Secretary : F. H. C. Butler, Ravensmead, Keston, Kent; Warden of Flatford Mill Field Centre: E. A. R. Ennion; Warden of Juniper Hall Field Centre: G. E. Hutchings; Assistant Wardens: J. H. Barrett, E. J. Douglas, J. H. P. Sankey. A central office for the Council will be opened shortly in South Kensington.

\section{Bradford Technical College}

THe application of the Bradford City Council to the University Grants Committee for the recognition of Bradford Technical College as a university college ranking for a Treasury grant has been refused. In communicating this decision, the University Grants Committee has stated that it considers the application of the term 'university college' to an institution primarily or exclusively technological in scope to be inappropriate and confusing; the distinction is not one of rank or status, but of kind. The Committee also pointed out that financial support for a college of which the primary function is technology is a matter for the Ministry of Education and not for the University Grants Committee. Following consideration of the report of the University Grants Committee at a meeting on June 18, Bradford Further Education Sub-Committee decided to seek an interview with both the Chancellor of the Exchequer and the Minister of Education to investigate further the possibilities of securing for the College university status.

\section{"A Century of British Chemistry"}

WE have received "A Century of British Chemistry", by Dr. F. Sherwood Taylor, published for the British Council by Longmans, Green and Co., Ltd. (ls. $6 d$. net). This is intended to mark the centenary celebrations of the Chemical Society, which were due in 1941 but were postponed on account of the War (see Nature of July 5, p. 6). The booklet deals with the contributions of British men of science to various branches of chemistry during the century in which the Society has been in existence; but as no historically sound document could be produced on such lines alone, account has also been taken in some places of the contributions of other nations in initiating or extending chemical knowledge. The booklet includes plates of portraits and illustrations of apparatus of historical interest. There is an index.

\section{History of Chemistry}

THE University of Pennsylvania Press is initiating an annual publication on the history of chemistry, entitled Chymia. A volume will consist of about a dozen articles, each of about 4,000-5,000 words, contributed by outstanding scholars from all over the world. The publication is sponsored by the Edgar F. Smith Memorial Collection at the University of Pennsylvania, a well-known collection of rare books, manuscripts, prints, and other items of interest in the development of chemistry. Publication will be under the direction of a board of American editors with a group of consulting editors, all of international prominence. The first number is ready for the press and will probably be issued this autumn. The Oxford University Press will publish Chymia in Great Britain. Requests for further information should be addressed to Eva V. Armstrong, secretary of the Board of Editors, Edgar F. Smith Collection, Harrison Laboratory, University of Pennsylvania, Philadelphia 4. 